\title{
AKTIVITAS ANTIOKSIDAN Padina sp. PADA BERBAGAI SUHU DAN LAMA PENGERINGAN
}

\section{Antioxidant Activity of Padina sp. at Various Temperature and Drying Time}

\author{
Amir Husni ${ }^{*}$, Deffy R. Putra ${ }^{1}$, dan Iwan Yusuf Bambang Lelana ${ }^{1}$ \\ ${ }^{1}$ Jurusan Perikanan, Fakultas Pertanian, Universitas Gadjah Mada, Jl. Flora Gedung A4 Bulaksumur \\ Yogyakarta, Indonesia \\ * Korespondensi Penulis: a-husni@ugm.ac.id
}

Diterima: 9 September 2014; Disetujui: 25 November 2014

\begin{abstract}
ABSTRAK
Penelitian ini bertujuan untuk mengetahui pengaruh suhu dan lama pengeringan dalam oven terhadap aktivitas antioksidan Padina sp. Pengeringan dilakukan pada suhu 50,55 , dan $60{ }^{\circ} \mathrm{C}$ masing-masing selama 4, 6, dan 8 jam. Sebagai pembanding dilakukan pengeringan di bawah sinar matahari selama 8 jam. Parameter yang diamati meliputi rendemen, kadar air, aktivitas antioksidan, total fenol, dan uji fitokimia. Hasil penelitian menunjukkan bahwa rendemen Padina sp. berkisar antara 12,86-18,28\%, kadar air 14,52-21,80\%, IC ${ }_{50}$ antioksidan 37,68-48,03 ppm, total fenol 0,18-0,35 mg PGE/mg, dan hasil uji fitokimia menunjukkan bahwa Padina sp. mengandung senyawa fenol. Pengeringan oven bersuhu $50{ }^{\circ} \mathrm{C}$ selama 4 jam menghasilkan aktivitas antioksidan dan total fenol tertinggi, dengan nilai $\mathrm{IC}_{50} 37,68 \mathrm{ppm}$ dan total fenol $0,35 \mathrm{mg}$ $\mathrm{PGE} / \mathrm{mg}$.
\end{abstract}

KATA KUNCl: Padina sp., antioksidan, pengeringan oven

\begin{abstract}
The objective of this study was to determine the effect of temperature and drying time in the oven on antioxidant activity of Padina sp. Drying was carried out at 50,55 , and $60^{\circ} \mathrm{C}$, respectively, for 4, 6, and 8 hours. For comparison, sun drying was conducted for 8 hours. Parameters observed was including yield, moisture content, antioxidant activity, total phenolic content and phytochemical test. The results showed that yield of Padina sp. ranged between 12.86-18.28\%; and moisture content, $I C_{50}$ antioxidant activity, total phenolic content were 14.52-21.80\%, 37.68-48.03 ppm, 0.18-0.35 mg PGE/mg extract, respectively. Phytochemical test showed that Padina sp. contained phenolic compounds. Drying oven at $50{ }^{\circ} \mathrm{C}$ for 4 hours produced Padina sp. with the highest antioxidant activity $I C_{50}(37.68 \mathrm{ppm})$ and total phenolic compounds (0.35 $\mathrm{mg}$ PGE/mg extract).
\end{abstract}

KEYWORDS: Padina sp., antioxidant, oven drying

\section{PENDAHULUAN}

Senyawa antioksidan adalah senyawa kimia yang dapat meredam radikal bebas dengan cara menyumbangkan satu atau lebih elektron kepada radikal bebas (Zubia et al., 2007). Radikal bebas merupakan atom atau molekul yang sifatnya sangat tidak stabil dan reaktif, serta merusak jaringan Radikal bebas inilah yang menjadi sumber penyakit degeneratif seperti diabetes melitus dan penyakit lainnya seperti pengerasan pembuluh darah, jantung koroner, stroke, dan kanker (Kang et al., 2010)

Tubuh manusia tidak mempunyai cadangan antioksidan dalam jumlah berlebih, sehingga jika terjadi paparan radikal berlebih maka tubuh membutuhkan antioksidan eksogen. Berdasarkan sumbernya, antioksidan eksogen dibagi menjadi dua yaitu antioksidan alami dan antioksidan sintetik. Meskipun beberapa jenis antioksidan sintetik telah diijinkan penggunaannya dalam produk pangan, namun tetap harus diwaspadai terutama terkait dengan dosis penggunaannya. Hal ini dikarenakan efek samping berbahaya yang mungkin terjadi ketika penggunaannya berlebihan atau dalam jangka waktu lama. Sebagai contoh: butylated hydoxyanisole (BHA), butylatedhydroxytoluene (BHT) dan propylgallate (PG) mempunyai efek samping yaitu dapat merusak hati dan dapat bersifat karsinogen (Kumar et al., 2008), 
oleh karena itu perlu dicari sumber-sumber antioksidan alami yang relatif lebih aman penggunaannya (Sunarni, 2005).

Salah satu sumber antioksidan alami adalah rumput laut. Rumput laut memiliki senyawa polifenol yang banyak ditemukan pada beberapa famili Alariceae, Fucaceae, dan Sargassaceae (Firdaus, 2011). Menurut Rice-Evans et al. (1997), polifenol dapat bersifat sebagai antioksidan karena senyawa ini memiliki sifat pereduksi, yakni agen pendonor atau penyumbang hidrogen. Padina sp. merupakan salah satu spesies rumput laut cokelat yang dilaporkan memiliki aktivitas antioksidan (Armah et al., 1999; Amornlerdpison et al., 2007, Zubia et al., 2007; Matanjun et al., 2008; Kumar et al., 2010; Siddhanta et al., 2010). Chew et al. (2008) melaporkan bahwa Padina antillarum memiliki aktivitas antioksidan paling tinggi dibandingkan dengan Caulerpa racemosa dan Kappaphycus alvarezzi.

Antioksidan bersifat sensitif terhadap cahaya dan panas, oleh karena itu penanganan bahan baku sumber antioksidan harus baik dan dihindarkan dari berbagai faktor yang dapat menurunkan aktivitasnya. Di lain pihak, usaha pengembangan produk antioksidan alami memerlukan penyediaan bahan baku yang terus menerus. Bahan baku dalam bentuk segar berpotensi menghasilkan aktivitas antioksidan yang tinggi namun kontinuitasnya mungkin sulit terjamin karena harus selalu diadakan setiap saat diperlukan. Selain itu bahan baku segar relatif lebih cepat rusak dibandingkan dalam bentuk kering. Pengeringan rumput laut dapat mereduksi kadar air, sehingga dapat memperpanjang daya simpannya. Salah satu metode pengeringan yang dapat digunakan adalah metode pengovenan. Metode pengovenan memiliki kelebihan antara lain suhu lebih stabil dibandingkan dengan pengeringan di bawah sinar matahari, mudah dilakukan, dan lebih murah dibandingkan dengan metode freeze drying (Chan et al., 1997). Penelitian ini bertujuan untuk mengetahui pengaruh suhu dan lama pengeringan dalam oven terhadap aktivitas antioksidan Padina sp.

\section{BAHAN DAN METODE}

\section{Bahan dan Alat}

Bahan baku yang digunakan adalah Padina sp. yang didapatkan dari Pantai Drini, Gunung Kidul. Bahan-bahan lain yang diperlukan untuk ekstraksi dan analisis antara lain adalah metanol, reagen Folin Ciocalteu, $\mathrm{Na}_{2} \mathrm{CO}_{3} 20 \%$, asam askorbat, phloroglucinol, dan larutan DPPH 0,15 mM. Peralatan yang digunakan dalam penelitian ini antara lain Erlenmeyer, spektofotometer UV-Vis, oven, centrifuge
(Eppendroft 5810R), waterbath shaker, dan vacuum rotary evaporator serta freeze dryer.

\section{Metode}

Penelitian ini dilakukan dengan tahapan sebagai berikut: pengeringan rumput laut, ekstraksi rumput laut, analisis aktivitas antioksidan, analisis kadar total senyawa fenol dan analisis fitokimia.

\section{Pengeringan rumput laut}

Sampel Padina sp. dicuci dengan air mengalir sampai bersih, kemudian ditimbang dan dioven pada suhu 50,55 , dan $60^{\circ} \mathrm{C}$ masing-masing selama 4, 6, dan 8 jam. Sebagai kontrol, Padina sp dikeringkan. di bawah sinar matahari selama 8 jam (jam 08.0016.00). Setelah pengeringan dilakukan analisis meliputi rendemen (Hikmah et al., 2009) dan kadar air (AOAC, 2000).

\section{Ekstraksi rumput laut}

Ekstraksi rumput laut dilakukan dengan metode maserasi bertingkat sebagaimana dilakukan oleh Firdaus et al. (2010). Setelah pengeringan, sampel dikecilkan ukurannya dan diayak dengan menggunakan saringan halus. Sampel dimasukkan ke dalam erlenmeyer yang dilapisi aluminium foil dan ditambahkan metanol (1:10). Sampel dimaserasi di dalam waterbath shaker $\left(28^{\circ} \mathrm{C} ; 100 \mathrm{rpm}\right)$ selama 6 jam kemudian difiltrasi (Filtrat 1). Residu 1 dilarutkan dalam metanol (1:10) dan dimaserasi kembali selama 1 jam kemudian difiltrasi (Filtrat 2). Residu 2 dilarutkan dalam metanol (1:10) dan dimaserasi kembali selama 1 jam kemudian difiltrasi (Filtrat 3). Filtrat 1, 2, dan 3 divorteks dan disentrifugasi dengan kecepatan 3200 $\mathrm{rpm}, 20^{\circ} \mathrm{C}$ selama 20 menit lalu diuapkan pelarutnya menggunakan vacuum rotary evaporator suhu $38^{\circ} \mathrm{C}$ hingga pekat. Ekstrak pekat yang diperoleh kemudian dikeringkan dengan menggunakan freeze dryer.

\section{Analisis aktivitas antioksidan}

Aktivitas antioksidan dianalisis dengan metode radical scavenging activity (RSA) DPPH sebagaimana dijelaskan oleh Chew et al. (2008). Ekstrak Padina sp. dibuat menjadi 6 seri pengenceran yaitu 0 ppm, 10, 20, 30, 40, dan 50 ppm. Sebanyak 0,5 ml dari masing-masing seri pengenceran ditambahkan $2 \mathrm{ml}$ larutan DPPH 0,15 mM kemudian dihomogenkan dengan vorteks. Setelah homogen, diinkubasi selama 30 menit pada suhu kamar dan kondisi gelap (dilapisi dengan alumunium foil). Absorbansi diukur pada panjang gelombang $517 \mathrm{~nm}$ menggunakan spektrofotometer UV-Vis. Aktivitas antioksidan dihitung berdasarkan persamaan regresi liniernya dan dinyatakan dalam $I_{50}(\mathrm{ppm})$. Asam askorbat 
digunakan sebagai pembanding senyawa antioksidan komersial dengan konsentrasi 0,1-0,5 ppm.

\section{Analisis kadar total senyawa fenol}

Penentuan kadar total senyawa fenol dilakukan dengan metode Folin Ciocalteu (Zubia et al., 2007). Ekstrak 10 ppm diambil 0,1 ml, dipindahkan ke tabung reaksi lalu ditambahkan 2,9 $\mathrm{ml}$ akuades dan 0,5 $\mathrm{ml}$ reagen Folin-Ciocalteu. Campuran didiamkan selama 10 menit; setelah itu ditambahkan 1,5 ml larutan $\mathrm{Na}_{2} \mathrm{CO}_{3} 20 \%$ dan didiamkan selama 1 jam pada suhu kamar dan kondisi gelap (dilapisi dengan alumunium foil). Absorbansi sampel diukur pada panjang gelombang $725 \mathrm{~nm}$ menggunakan spektrofotometer UV-Vis. Total senyawa fenolik dihitung berdasarkan persamaan regresi linier kurva standar floroglusinol dan dinyatakan dalam mg PGE/mg ekstrak.

\section{Analisis data}

Data yang diperoleh dianalisis menggunakan analisis sidik ragam (analysis of variance) dengan tingkat kepercayaan 95\%. Jika hasil analisis menunjukkan beda nyata maka dilakukan uji Duncan's Multiple Range Test (DMRT) untuk mengetahui beda nyata antar perlakuan (Gomez \& Gomez, 1984).

\section{HASIL DAN PEMBAHASAN}

\section{Rendemen}

Hasil penelitian menunjukkan bahwa rendemen Padina sp. setelah pengeringan dengan menggunakan oven berkisar antara $12,86 \%$ hingga $17,02 \%$. Rendemen perlakuan kontrol dengan pengeringan di bawah sinar matahari selama 8 jam adalah 18,28\%. Grafik rendemen Padina sp. dapat dilihat pada Gambar 1.

Analisis sidik ragam rendemen Padina sp. kering menunjukkan bahwa faktor suhu, lama waktu, dan interaksi antara suhu dan lama pengeringan memberikan pengaruh yang nyata terhadap rendemen. Hasil uji DMRT menunjukkan bahwa 6 perlakuan yang diberikan berbeda nyata, yaitu perlakuan pengeringan dengan menggunakan oven suhu $50^{\circ} \mathrm{C}$ selama 4 jam, $50^{\circ} \mathrm{C}$ selama 8 jam, $55^{\circ} \mathrm{C}$ selama 6 jam, $60^{\circ} \mathrm{C}$ selama 6 jam, dan $60^{\circ} \mathrm{C}$ selama 8 jam serta perlakuan kontrol pengeringan di bawah sinar matahari selama 8 jam.

Berdasarkan Gambar 1 secara umum rendemen Padina sp. semakin menurun seiring dengan meningkatnya suhu pengovenan. Pada suhu pengovenan yang sama, rendemen juga semakin menurun seiring dengan lama waktu pengovenan. Hal tersebut dikarenakan semakin lama proses pengeringan dengan oven maka kandungan air bebas yang menguap akan semakin besar sehingga massa bahan kering yang dihasilkan juga akan semakin menurun (Sudarmadji et al., 2007). Hasil penelitian ini serupa dengan hasil penelitian Hikmah et al. (2009) terhadap antioksidan Spirulina platensis yaitu bahwa semakin tinggi penggunaan suhu pengovenan dan semakin lama waktu pengovenan menyebabkan penurunan rendemen.

Perlakuan kontrol yaitu pengeringan di bawah sinar matahari selama 8 jam menghasilkan rendemen tertinggi dibandingkan dengan semua perlakuan pengovenan. Hal tersebut disebabkan karena kandungan air bebas Padina sp. yang diberi perlakuan ini tidak dapat menguap secara konstan karena suhu pengeringan di bawah sinar matahari cenderung tidak konstan. Selain itu suhu tertinggi pengeringan dengan sinar matahari umumnya, masih di bawah suhu terendah perlakuan pengeringan dengan oven, sehingga kecepatan penguapan air lebih lambat. Akibatnya pengeringan dengan matahari menghasilkan produk dengan kadar air yang paling tinggi (Gambar 2); dan hal ini berdampak pada rendemen yang memiliki pola serupa dengan kadar air. Makin tinggi kadar air, rendemen semakin tinggi juga. Rendemen teritnggi dari perlakuan pengovenan dihasilkan oleh perlakuan pengovenan suhu $50{ }^{\circ} \mathrm{C}$ selama 4 jam. Perlakuan pengeringan dengan menggunakan suhu yang lebih stabil lebih baik dilakukan karena dapat mempercepat proses pengeringan.

\section{Kadar Air}

Kadar air Padina sp. dapat dilihat pada Gambar 2. Kadar air Padina sp. hasil pengeringan dengan menggunakan oven berkisar antara 14,52-20,63\% dan kadar air Padina sp. hasil pengeringan di bawah sinar matahari adalah 21,80\%. Hasil analisis sidik ragam kadar air menunjukkan bahwa faktor suhu, lama waktu, dan interaksi antara suhu dan lama waktu pengeringan memberikan pengaruh nyata terhadap kadar air. Hasil uji DMRT menunjukkan bahwa perlakuan kontrol dan 5 perlakuan pengeringan dengan menggunakan oven memberikan pengaruh yang nyata terhadap kadar air, yaitu perlakuan A0B0, A1B1, A1B3, A2B2, A3B2, dan A3B3.

Kadar air hasil pengeringan dengan menggunakan oven semakin menurun seiring dengan meningkatnya suhu yang diberikan. Hal tersebut disebabkan oleh penguapan yang terjadi akibat suhu pemanasan yang semakin tinggi (Hikmah et al., 2009). Perlakuan pengovenan pada suhu $60{ }^{\circ} \mathrm{C}$ selama 8 jam 


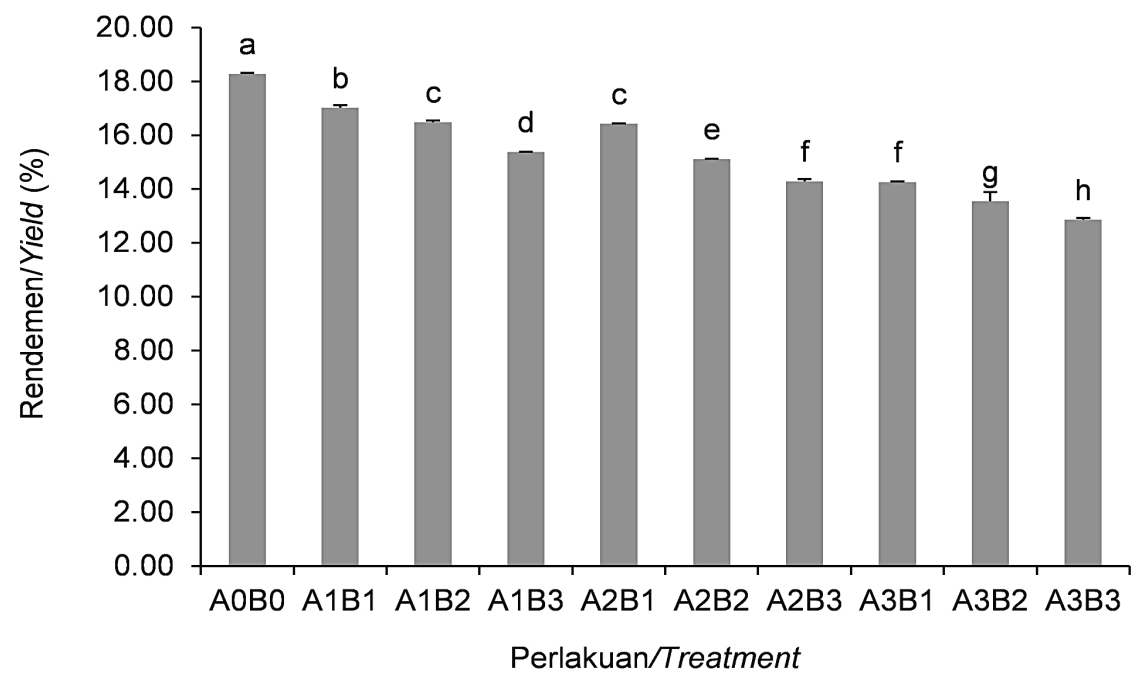

Keterangan/Note:

Huruf yang sama menunjukkan tidak beda nyata/Same letter indicate not significant.

$$
\begin{aligned}
& \mathrm{A} 1=50^{\circ} \mathrm{C} \quad \mathrm{B} 1=4 \mathrm{Jam} / \mathrm{h} \\
& \mathrm{A} 2=55^{\circ} \mathrm{C} \quad \mathrm{B} 2=6 \mathrm{Jam} / \mathrm{h} \\
& \mathrm{A} 3=60^{\circ} \mathrm{C} \quad \mathrm{B} 3=8 \mathrm{Jam} / \mathrm{h} \\
& \mathrm{A} 0 \mathrm{BO}=\text { Pengeringan di bawah sinar matahari (8 Jam)/Sun drying (8 h) }
\end{aligned}
$$

Gambar 1. Pengaruh suhu dan lama pengeringan terhadap rendemen Padina sp. Figure 1. Effect of temperature and drying time on yield of Padina sp.

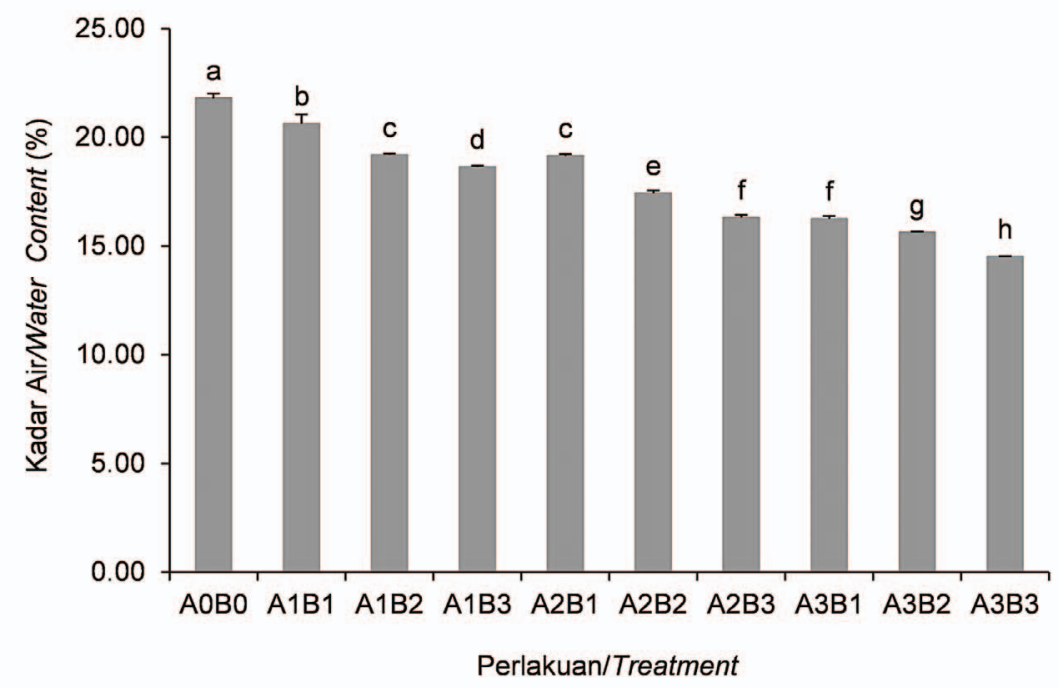

Keterangan/Note:

Huruf yang sama menunjukkan tidak beda nyata/Same letter indicate not significant.

$$
\begin{array}{ll}
\mathrm{A} 1=50^{\circ} \mathrm{C} & \mathrm{B} 1=4 \mathrm{Jam} / \mathrm{h} \\
\mathrm{A} 2=55^{\circ} \mathrm{C} & \mathrm{B} 2=6 \mathrm{Jam} / \mathrm{h} \\
\mathrm{A} 3=60^{\circ} \mathrm{C} & \mathrm{B} 3=8 \mathrm{Jam} / \mathrm{h}
\end{array}
$$

$\mathrm{AOBO}=$ Pengeringan di bawah sinar matahari $(8 \mathrm{Jam}) /$ Sun drying $(8 \mathrm{~h})$

Gambar 2. Pengaruh suhu dan waktu pengeringan terhadap kadar air Padina sp. Figure 2. Effect of drying time dan temperature on water content of Padina sp. 
menghasilkan kadar air yang paling rendah dibandingkan dengan perlakuan lainnya. Kadar air suatu bahan berhubungan dengan daya simpan bahan, karena air yang terkandung dalam bahan dapat menjadi media tumbuh bagi mikrobia yang menyebabkan kerusakan (Usmiati \& Nurdjannah, 2007).

\section{Aktivitas Antioksidan}

Aktivitas antioksidan pada masing-masing perlakuan dapat dilihat pada Tabel 1. Semakin tinggi konsentrasi ekstrak yang digunakan, aktivitas penghambatan RSAnya juga meningkat. Sampai dengan konsentrasi 50 ppm, penghambatan tertinggi diperoleh pada perlakuan pengeringan dengan pengovenan suhu $50^{\circ} \mathrm{C}$ selama 4 jam.

Analisis sidik ragam aktivitas antioksidan Padina sp. menunjukkan bahwa faktor suhu, lama waktu, dan interaksi antara suhu dan lama waktu pengeringan berbeda nyata terhadap aktivitas antioksidan. Nilai IC antioksidan Padina sp. dapat dilihat pada Gambar 3. Hasil uji DMRT menunjukkan bahwa 4 perlakuan pengovenan berbeda nyata, yaitu pengovenan bersuhu $50{ }^{\circ} \mathrm{C}$ selama 4 jam, $50{ }^{\circ} \mathrm{C}$ selama 8 jam, $55^{\circ} \mathrm{C}$ selama 6 jam, dan $60{ }^{\circ} \mathrm{C}$ selama 6 jam. Nilai IC ${ }_{50}$ antioksidan pada Gambar 3 dapat diartikan bahwa semakin rendah nilai $\mathrm{IC}_{50}$ antioksidan maka semakin tinggi aktivitas antioksidannya. Hal tersebut disebabkan karena dengan penggunaan konsentrasi yang semakin rendah sudah dapat menghambat
DPPH sebesar 50\% (Prior \& Cao, 1999). Nilai IC antioksidan hasil penelitian ini meningkat seiring dengan meningkatnya suhu dan lama waktu pengovenan. Hal tersebut berarti bahwa aktivitas antioksidan Padina sp. dapat menurun akibat perlakuan suhu dan lama waktu pengeringan oven.

Perlakuan pengovenan bersuhu $50^{\circ} \mathrm{C}$ selama 4 jam menghasilkan nilai $\mathrm{IC}_{50}$ antioksidan yang paling rendah dibandingkan dengan nilai $\mathrm{IC}_{50}$ antioksidan perlakuan yang lain yaitu sebesar 37,68 ppm. Nilai $\mathrm{IC}_{50}$ tersebut dapat diartikan bahwa dengan penggunaan 37,68 ppm ekstrak Padina sp. dapat menghambat DPPH 0,15 mM sebesar 50\%. Nilai IC antioksidan perlakuan pengovenan bersuhu $50{ }^{\circ} \mathrm{C}$ selama 4 jam yang paling rendah menunjukkan aktivitas antioksidan yang paling tinggi dibandingkan dengan perlakuan pengovenan lainnya. Perlakuan pengovenan bersuhu $60^{\circ} \mathrm{C}$ selama 8 jam nilai IC antioksidannya adalah 48,03 ppm, paling tinggi dibandingkan dengan nilai $I C_{50}$ antioksidan perlakuan pengovenan lainnya. Nilai tersebut menunjukkan aktivitas antioksidan yang paling rendah dibandingkan dengan perlakuan pengovenan lainnya. Dengan IC $\mathrm{I}_{50}$ tersebut menunjukkan bahwa ekstrak Padina sp. termasuk antioksidan yang sangat kuat karena mempunyai $I_{50}<50$ ppm (Blois, 2005).

Chew et al. (2008) melaporkan bahwa nilai IC ${ }_{50}$ antioksidan Padina sp. asal Malaysia yang dikeringbekukan adalah 0,34 ppm. $P$. australis dari perairan Sulawesi Utara yang dikeringkan dengan oven

Tabel 1. Pengaruh konsentrasi ekstrak Padina sp. terhadap aktivitas antioksidan (\% penghambatan RSA)

Table 1. Effect of extracts Padina sp. concentration on antioxidant activity (\% RSA inhibition)

\begin{tabular}{lrrrrrc}
\hline \multirow{2}{*}{$\begin{array}{c}\text { Sampel } \\
\text { Sample }\end{array}$} & \multicolumn{6}{c}{ KonsentrasilConcentration (ppm) } \\
\cline { 2 - 7 } & $\mathbf{0}$ & $\mathbf{1 0}$ & $\mathbf{2 0}$ & $\mathbf{3 0}$ & $\mathbf{4 0}$ & $\mathbf{5 0}$ \\
\hline A0B0 & 0 & 9.77 & 26.25 & 36.66 & 42.49 & 47.81 \\
A1B1 & 0 & 14.55 & 29.20 & 36.59 & 58.12 & 63.07 \\
A1B2 & 0 & 13.46 & 27.40 & 35.54 & 56.77 & 61.95 \\
A1B3 & 0 & 12.38 & 26.18 & 34.15 & 53.71 & 59.78 \\
A2B1 & 0 & 14.01 & 28.38 & 36.52 & 56.30 & 62.46 \\
A2B2 & 0 & 12.67 & 24.35 & 33.58 & 52.58 & 58.10 \\
A2B3 & 0 & 11.54 & 23.67 & 32.41 & 51.27 & 55.59 \\
A3B1 & 0 & 11.61 & 23.46 & 32.66 & 51.31 & 55.59 \\
A3B2 & 0 & 10.37 & 23.14 & 32.17 & 47.59 & 52.87 \\
A3B3 & 0 & 9.71 & 26.40 & 37.03 & 42.01 & 47.92 \\
\hline
\end{tabular}

Keterangan/Note:

$\begin{array}{lll}\mathrm{A} 1=50^{\circ} \mathrm{C} & \mathrm{A} 3=60^{\circ} \mathrm{C} & \mathrm{B} 2=6 \mathrm{Jam} / \mathrm{h} \\ \mathrm{A} 2=55^{\circ} \mathrm{C} & \mathrm{B} 1=4 \mathrm{Jam} / \mathrm{h} & \mathrm{B} 3=8 \mathrm{Jam} / \mathrm{h}\end{array}$

$\mathrm{AOBO}=$ Pengeringan di bawah sinar matahari (8 Jam)/Sun drying (8 $h$ ) 


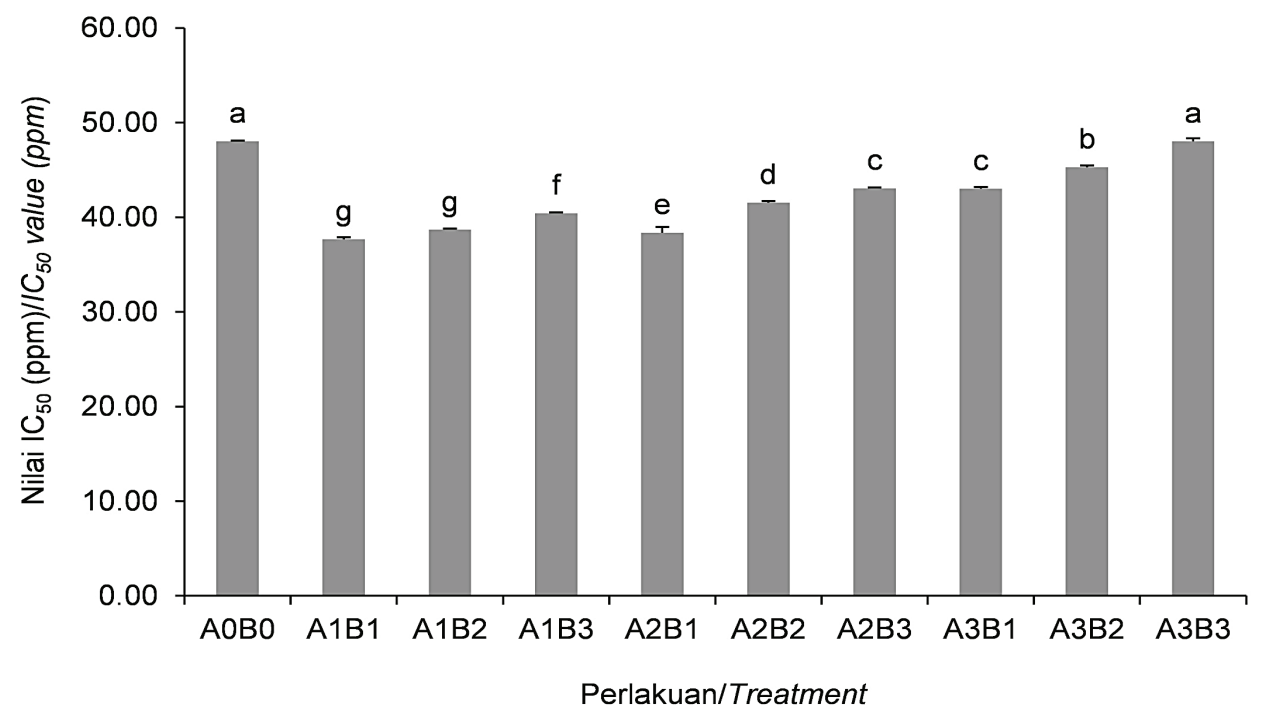

Keterangan/Note:

Huruf yang sama menunjukkan tidak beda nyata/Same letter indicate not significant.

$$
\begin{aligned}
& \mathrm{A} 1=50^{\circ} \mathrm{C} \quad \mathrm{B} 1=4 \mathrm{Jam} / \mathrm{h} \\
& \mathrm{A} 2=55^{\circ} \mathrm{C} \quad \mathrm{B} 2=6 \mathrm{Jam} / \mathrm{h} \\
& \mathrm{A} 3=60^{\circ} \mathrm{C} \quad \mathrm{B} 3=8 \mathrm{Jam} / \mathrm{h} \\
& \mathrm{AOBO}=\text { Pengeringan di bawah sinar matahari }(8 \mathrm{Jam}) / \text { Sun drying }(8 \mathrm{~h})
\end{aligned}
$$

Gambar 3. Pengaruh suhu dan waktu pengeringan terhadap aktivitas antioksidan Padina sp.

Figure 3. Effect of drying time dan temperature on antioxidant acivity of Padina sp.

suhu ruang dilanjutkan dengan oven suhu $40{ }^{\circ} \mathrm{C}$ selama 4-6 jam, pada konsentrasi 4000 ppm menghasilkan nilai antioksidan $15,74-21,65 \%$ penghambatan RSA (Dotulong et al., 2013). Penanganan bahan baku tampaknya berpengaruh besar terhadap aktivitas antioksidan Padina sp. Beberapa faktor lainnya yang berpengaruh terhadap aktivitas antioksidan adalah faktor eksternal seperti nutrisi, kedalaman, dan salinitas habitat Padina sp. serta faktor internal seperti umur dan tingkat reproduksi (Zubia et al., 2007).

Aktivitas antioksidan Padina sp. yang mengalami pengeringan dengan menggunakan oven juga dibandingkan dengan antioksidan komersial Vitamin C. Berdasarkan hasil penelitian yang dilakukan terhadap aktivitas antioksidan Vitamin $\mathrm{C}$ dengan konsentrasi 0,1-0,5 ppm didapatkan nilai $I C_{50}$ sebesar $0,32 \mathrm{ppm}$. Nilai $I \mathrm{C}_{50}$ antioksidan ini 10 kali lebih kecil dibandingkan dengan Padina sp. pada semua perlakuan pengeringan. Hal ini dapat disebabkan karena ekstrak yang diuji masih berupa campuran berbagai senyawa, sedangkan Vitamin C merupakan senyawa murni.

\section{Kadar Total Senyawa Fenol}

Hasil perhitungan kadar total senyawa fenol Padina sp. setelah pengeringan berkisar antara 0,18 mg PGE/ mg ekstrak hingga 0,35 mgPGE/mg ekstrak (Gambar 4). Analisis sidik ragam kadar total fenol Padina sp. menunjukkan bahwa faktor suhu, lama waktu, dan interaksi antara suhu dan lama waktu pengeringan berbeda nyata terhadap kadar total fenol. Hasil uji DMRT menunjukkan bahwa 6 perlakuan berbeda nyata, yaitu pengovenan suhu $50^{\circ} \mathrm{C}$ selama 4 jam, $50{ }^{\circ} \mathrm{C}$ selama $8 \mathrm{jam}, 55^{\circ} \mathrm{C}$ selama $6 \mathrm{jam}, 60^{\circ} \mathrm{C}$ selama 6 jam, dan $60{ }^{\circ} \mathrm{C}$ selama 8 jam serta I pengeringan di bawah sinar matahari selama 8 jam.

Zubia et al. (2007) melaporkan bahwa kadar total fenol Padina sp. asal Playa de Carmen, Mexico yang dikeringbekukan adalah sebesar $0,56 \mathrm{mg} \mathrm{PGE/mg}$ ekstrak. $P$. australis dari perairan Sulawesi Utara yang dikeringkan dengan oven suhu $40^{\circ} \mathrm{C}$ selama 4-6 jam dilaporkan oleh Dotulong et al. (2013) mengandung kadar total fenol yang lebih tinggi, yaitu 3,55-8,37 mg GAE/g ekstrak. Berdasarkan Gambar 4 dapat dilihat bahwa kadar total fenol menurun seiring dengan meningkatnya suhu pengovenan dan lama waktu pengovenan, sebagaimana dilaporkan oleh Hikmah et al. (2009) bahwa kadar total senyawa fenol menurun akibat pengeringan dengan oven.

Kadar total fenol perlakuan kontrol (pengeringan di bawah sinar matahari) adalah 0,18 $\mathrm{mg}$ PGE/mg ekstrak. Kadar total fenol hasil pengeringan di bawah sinar matahari ini merupakan kadar total fenol yang paling rendah dibandingkan dengan perlakuan yang 


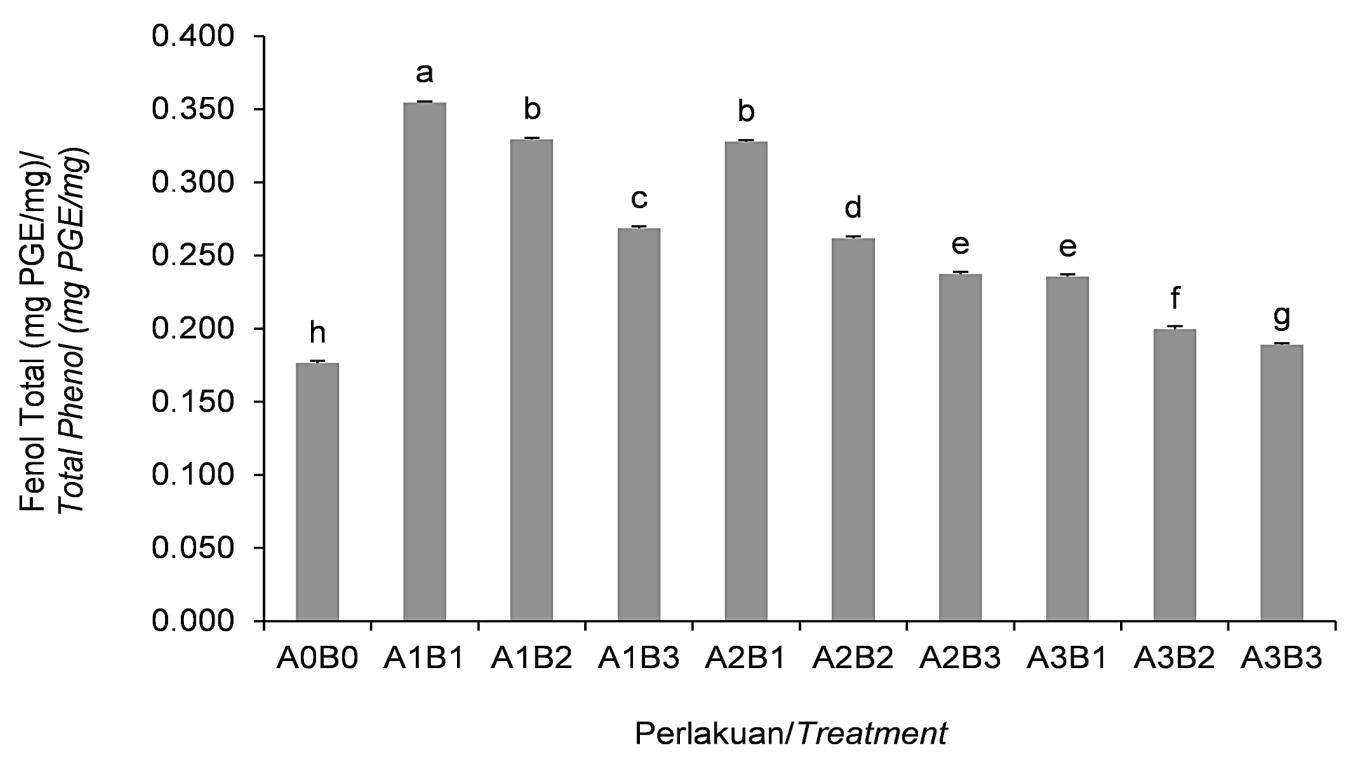

Keterangan/Note:

Huruf yang sama menunjukkan tidak beda nyata/Same letter indicate not significant.

$$
\begin{array}{ll}
\mathrm{A} 1=50^{\circ} \mathrm{C} & \mathrm{B} 1=4 \mathrm{Jam} / \mathrm{h} \\
\mathrm{A} 2=55^{\circ} \mathrm{C} & \mathrm{B} 2=6 \mathrm{Jam} / \mathrm{h} \\
\mathrm{A} 3=60^{\circ} \mathrm{C} & \mathrm{B} 3=8 \mathrm{Jam} / \mathrm{h} \\
\mathrm{A} 0 \mathrm{BO}=\text { Pengeringan di bawah sinar matahari }(8 \mathrm{Jam}) / \text { Sun drying }(8 \mathrm{~h})
\end{array}
$$

Gambar 4. Pengaruh suhu dan waktu pengeringan terhadap total senyawa fenol Padina sp.

Figure 4. Effect of drying time dan temperature on total phenolic content of Padina sp.

lain. Hal tersebut dapat disebabkan karena suhu pemanasan meskipun relatif lebih rendah tetapi cenderung tidak stabil dan dilakukan dalam waktu yang lebih lama. Tampak disini bahwa waktu pemanasan sangat berpengaruh terhadap penurunan kadar total fenol. Jahangiri et al. (2011) melaporkan bahwa proses pengeringan (suhu atau waktu pengeringan yang lama) dapat menghancurkan beberapa fenol karena dalam kondisi kering semua komponen dalam sel (misalnya: membran dan organel) menyatu sehingga ekstraksi fenol menjadi lebih sulit.

Kadar total fenol hasil pengeringan dengan menggunakan oven bersuhu $50^{\circ} \mathrm{C}$ selama 4 jam adalah $0,35 \mathrm{mg}$ PGE/mg ekstrak. Kadar total fenol perlakuan tersebut merupakan kadar total fenol yang paling tinggi dibandingkan dengan perlakuan kontrol dan perlakuan pengovenan lainnya. Hal tersebut disebabkan karena senyawa-senyawa fenol yang terdapat pada Padina sp. dapat bertahan lebih baik dibandingkan dengan perlakuan yang lain; Suhu yang diberikan lebih rendah dibandingkan dengan perlakuan pengovenan yang lain dan dilakukan dalam waktu yang lebih singkat. Perlakuan pengeringan dengan menggunakan oven bersuhu $50{ }^{\circ} \mathrm{C}$ selama 4 jam merupakan perlakuan terbaik untuk mendapatkan Padina sp. dengan kadar total fenol tertinggi.

\section{Korelasi Kadar Total Senyawa Fenol dan Aktivitas Antioksidan}

Aktivitas antioksidan erat hubungannya dengan kandungan metabolit sekunder yang berfungsi sebagai antioksidan seperti senyawa fenol (Zubia et al., 2007). Kurva korelasi kadar total senyawa fenol dan $\mathrm{IC}_{50}$ antioksidan hasil penelitian ini dapat dilihat pada Gambar 5.

Berdasarkan Gambar 5 dapat dilihat bahwa kadar total senyawa fenol berkorelasi negatif dengan $\mathrm{IC}_{50}$ antioksidannya. Berdasarkan koefisien determinasinya dapat diartikan bahwa $94 \%$ IC $_{50}$ antioksidan Padina sp. dipengaruhi oleh kadar total senyawa fenolnya. Nilai $I_{50}$ antioksidan yang semakin rendah menunjukkan aktivitas antioksidan yang semakin tinggi. Berdasarkan Gambar 5 dapat dinyatakan bahwa aktivitas antioksidan Padina sp. semakin meningkat seiring dengan meningkatnya kadar total senyawa fenol.

Menurut Andarwulan et al. (1996) pemanasan yang cukup lama dan menggunakan temperatur yang tinggi dapat menurunkan aktivitas antioksidan. Hasil korelasi ini mirip dengan penelitian Zubia et al. (2007) yang menyatakan bahwa ada interaksi antara kadar total senyawa fenol dengan aktivitas antioksidan 


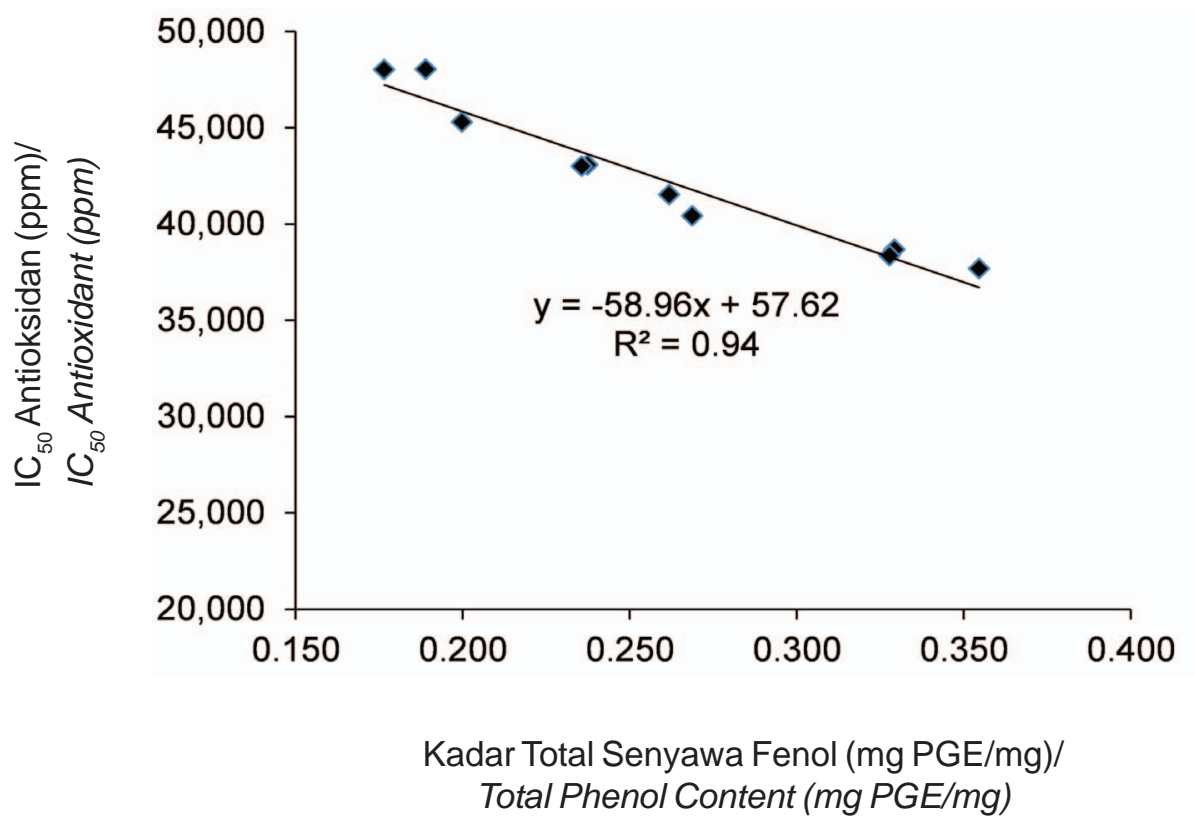

Gambar 5. Kurva korelasi kadar total senyawa fenol dan aktivitas antioksidan Padina sp. Figure 5. Correlation between total phenol content and antioxidant acitivity of Padina sp.

\begin{abstract}
Sargasssum sp. yang mengalami pengeringan dengan menggunakan oven. Polifenol dapat bersifat sebagai antioksidan karena kemampuannya mendonorkan atom hidrogen, menangkap radikal bebas, dan sebagai pengikat logam (Lee et al., 2004). Aktivitas antioksidan sangat ditentukan oleh reaktivitasnya sebagai agen pendonor hidrogen, reaktivitasnya dengan antioksidan yang lain, potensial transisi pengikatan logam, dan kemampuannya untuk menstabilisasi dan mendelokalisasi elektron tak berpasangan (RiceEvans et al., 1997).
\end{abstract}

\section{KESIMPULAN}

Penggunaan metode pengeringan oven dapat mempengaruhi rendemen, kadar air, aktivitas antioksidan, dan kadar total fenol Padina sp. Pengeringan Padina sp. dengan menggunakan oven bersuhu $50{ }^{\circ} \mathrm{C}$ selama 4 jam merupakan perlakuan terbaik untuk mendapatkan kadar total senyawa fenol tertinggi $(0,35 \mathrm{mg}$ PGE/mg ekstrak) dan aktivitas antioksidan yang maksimal ( $\left.\mathrm{IC}_{50} 37,68 \mathrm{ppm}\right)$. Dengan $\mathrm{IC}_{50}$ tersebut, ekstrak Padina sp. tergolong antioksidan yang sangat kuat $\left(\mathrm{IC}_{50}<50 \mathrm{ppm}\right)$.

\section{DAFTAR PUSTAKA}

Amornlerdpison, D., Peerapornpisal, Y., Taesotikul, T., Jamjai, U., Nualchaero, N., \& Kanjanapothi, D. (2007). Antioxidant activity of Padina minor Yamada. Journal of KMITL Science and Technology 7: 1-7.
Andarwulan, N., Wijaya, C.H., \& Cahyono, D.T. (1996). Aktivitas antioksidan dari daun sirih (Piper betle L.). Buletin Teknologi dan Industri Pangan. 7: 29-37.

[AOAC] Association of Official Analytical Chemistry. (2000). Official Method of Analysis. Association of Official Analytical Chemistry, Maryland.

Armah, Y.S., Nyarko, B.J.B., Osae, E.K., Carboo, D.M., \& Seku, F. (1999). Elemental analysis of some green and brown seaweeds from the coastal belt of Ghana. Journal of Radioanalytical and Nuclear Chemistry. 242: 193-197.

Blois, M.S. (2005). Antioxidant determination by the use of stable free radical. Nature. 181: 1191-1200.

Chan, J.C., Cheung, P.C.K., \& Ang, P.O. (1997). Comparative studies on the effect of three drying method on nutritional composition of seaweed Sargassum hemiphyllum (Turn). Journal of Agriculture and Food Chememistry. 45: 3056-3059.

Chew, Y.L., Lim, Y.Y., Omar, M., \& Khoo, K.S. (2008). Antioxidant activity of three edible seaweeds from two areas in South East Asia. LWT-Food Science and Technology. 41: 1067-1072.

Dotulong, V., Widjanarko, S.B., Yunianta, and Mamahit, L.P. (2014). Antioxidant activity of three-marine algae methanol extract collected from North Sulawesi Waters, Indonesia. International Journal of Science and Engineering Investigations. 2(23): 26-30.

Firdaus, M., Astawan, M., Muchtadi, D., Wresdiyati, T., Waspadji, S., \& Setyawati, S.K. (2010). Pengaruh ekstrak rumput laut cokelat terhadap fungsi sel Endotelium aorta tikus diabetes mellitus. Majalah Farmasi Indonesia. 21(3): 151-157.

Firdaus, M. (2011). Aktivitas Antioksidan Ekstrak Rumput Laut Coklat (Sargassum echinocarpum) sebagai 
Pencegah Disfungsi Sel Endotelium Aorta Tikus Diabetes Melitus. Disertasi. Sekolah Pascasarjana IPB. Bogor

Gomez, K.A. \& Gomez A.A. (1984). Statistical Procedures For Agriculural Research. John Willey and Sons. Canada.

Hikmah, A.F., Budhiyanti, S.A., \& Ekantari, N. (2009). Pengaruh pengeringan terhadap aktivitas antioksidan Spirulina platensis. Prosiding Seminar Nasional Tahunan VI Hasil Penelitian Perikanan dan Kelautan. PA-04: 1-11.

Jahangiri, Y., Ghahremani, H., Torghabeh, J.A., \& Salehi, E.A. (2011). Effect of temperature and solvent on the total phenolic compounds extraction from leaves of Ficus carica. Journal of Chemical and Pharmaceutical Research. 3(5): 253-259.

Kang, C., Jin, B., Lee, H., Cha, M., Sohn. E., Moon, J., Park, C., Chun, S., Jung, E., Hong, J.S., Kim, J., \& Kim, E. (2010). Brown algae Eclonia cava attenuates type 1 diabetes by activating AMPK and AKT signaling pathways. Journal of Food Chemistry and Toxicology. 48: $509-516$.

Kumar, P.S., Sucheta, S., Deepa, V.S., Selvamani, P., \& Latha, S. (2008). Antioxidant activity in the some selected Indian medical plants. African Journal of Biotechnology. 7(12): 1826-1828

Kumar, M., Puja, K., Vishal, G., Reddy, C.R.K., \& Jha, B. (2010). Minerals, PUFAs and antioxidant properties of some tropical seaweeds from saurashtra coast of India. Journal of Applied Phycology. 23: 797-810.

Lee, J., Koo, N., \& Min, D.B. (2004). Reactive oxygen species, aging, and antioxidative nutrceuticals. Comprehensive Reviews in Food Science and Food Safety. 3: 21-33.
Matanjun, P., Mohamed, S., Mustapha, N.M., Muhammad, K., \& Ming, C.H. (2008). Antioxidant activities and phenolics content of eight species of seaweeds from North Borneo. Journal of Applied Phycology. 20: 367373.

Prior, R.L. \& Cao, G. (1999). In vivo total antioxidant capacity: comparison of different analytical methods. Journal of Free Radical and Biological Medicine 27: 1173-1181.

Rice-Evans, C.A., Miller, N.J., \& Paganga, G. (1997). Antioxidant properties of phenolic compounds. Trend Planta Sciences Review. 2: 152-159.

Siddhanta, A.K., Prasad, K., Meena, R., Prasad, G., Mehta, G.K., Chhatbar, M.U., Oza, M.D., Kumar, S., \& Sanandiya, N. (2010). The cellulose contents of Indian seaweeds. Journal of Applied Phycology. 23: 919923.

Sudarmadji, S., Haryono, B., \& Suhardi. (2007). Analisa Bahan Makanan dan Pertanian. Liberty. Yogyakarta.

Sunarni, T. (2005). Aktivitas antioksidan penangkap radikal bebas beberapa kecambah dari biji tanaman familia Papilionaceae. Jurnal Farmasi Indonesia. 2: 53-61.

Usmiati, S. \& Nurdjannah, N. (2007). Pengaruh lama perendaman dan cara pengeringan terhadap mutu lada putih. Jurnal Pertanian Indonesia. 16(3): 9198.

Wagner, H., Bladt, S., \& Zgainski, E.M. (1984). Plant Drug Analysis A Thin Layer Chromathography Atlas (Transalted By Schoot, P.B). Springer, Verlag, Tokyo.

Zubia, M., Robledo, D., \& Freile-Pelegrin Y. (2007). Antioxidant activities in marine macroalgae from the coasts of quintana Roo and Yucatan, Mexico. Journal of Applied Phycology. 19: 449-458. 